\title{
'For great in your midst is the Holy One of Israel' (Is 12:6b): Trauma and resilience in the Isaianic Psalm

\begin{tabular}{|c|c|}
\hline $\begin{array}{l}\text { Author: } \\
\text { Alphonso Gro }\end{array}$ & ewald'® \\
\hline $\begin{array}{l}\text { Affiliation: } \\
{ }^{1} \text { Department } \\
\text { Testament Stc } \\
\text { Theology, Uni } \\
\text { Pretoria, Sout }\end{array}$ & $\begin{array}{l}\text { of Old } \\
\text { Idies, Faculty of } \\
\text { versity of } \\
\text { h Africa }\end{array}$ \\
\hline $\begin{array}{l}\text { Research Proj } \\
\text { Project Leade } \\
\text { Project Numb }\end{array}$ & $\begin{array}{l}\text { ect Registration: } \\
\text { : A. Groenewald } \\
\text { er: } 02428024\end{array}$ \\
\hline $\begin{array}{l}\text { Description: } \\
\text { This research } \\
\text { project 'Exege } \\
\text { Theology of Is } \\
\text { by Prof. Dr Alp } \\
\text { Groenewald, } \\
\text { Old Testamen } \\
\text { Faculty of The } \\
\text { University of }\end{array}$ & $\begin{array}{l}\text { is part of the } \\
\text { sis and the } \\
\text { aiah', directed } \\
\text { shonso } \\
\text { Department of } \\
\text { t Studies, } \\
\text { ology, } \\
\text { Pretoria. }\end{array}$ \\
\hline $\begin{array}{l}\text { Correspondin } \\
\text { Alphonso Gro } \\
\text { alphonso.groe } \\
\text { ac.za }\end{array}$ & $\begin{array}{l}\text { g author: } \\
\text { enewald, } \\
\text { enewald@up. }\end{array}$ \\
\hline $\begin{array}{l}\text { Dates: } \\
\text { Received: } 20 \text { S } \\
\text { Accepted: } 26 \\
\text { Published: } 07\end{array}$ & $\begin{array}{l}\text { Sept. } 2017 \\
\text { Sept. } 2017 \\
\text { Nov. } 2017\end{array}$ \\
\hline $\begin{array}{l}\text { How to cite th } \\
\text { Groenewald, } \\
\text { great in your r } \\
\text { Holy One of Is } \\
\text { Trauma and re } \\
\text { Isaianic Psalm } \\
\text { Teologiese Stu } \\
\text { Theological St } \\
\text { a4820. https:/ } \\
\text { 10.4102/hts.V }\end{array}$ & $\begin{array}{l}\text { is article: } \\
\text { A., 2017, “"For } \\
\text { nidst is the } \\
\text { rael” (Is 12:6b): } \\
\text { silience in the } \\
\text {, HTS } \\
\text { dies/ } \\
\text { udies 73(4), } \\
\text { /doi.org/ } \\
\text { 73i4.4820 }\end{array}$ \\
\hline $\begin{array}{l}\text { Copyright: } \\
\text { (c) 2017. The A } \\
\text { Licensee: AOS } \\
\text { is licensed unc } \\
\text { Creative Comr } \\
\text { Attribution Lic }\end{array}$ & $\begin{array}{l}\text { uthors. } \\
\text { IS. This work } \\
\text { der the } \\
\text { nons } \\
\text { ense. }\end{array}$ \\
\hline Read online: & \\
\hline 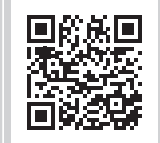 & $\begin{array}{l}\text { Scan this QR } \\
\text { code with your } \\
\text { smart phone or } \\
\text { mobile device } \\
\text { to read online. }\end{array}$ \\
\hline
\end{tabular}

This article focuses on Isaiah 12 - an important text that concludes the first main section of the Book of Isaiah (BI). The analysis focuses on the structure and redaction of this text. The text is interpreted as a meaning-making text against the background of trauma as described in this first main section of the BI.

\section{Introduction}

Isaiah 12 marks a major break in the composition of the Book of Isaiah (BI). This chapter - a psalmlike passage - concludes the first section of the written corpus of the Isaianic oracles. The new heading in Isaiah 13:1 introduces the chapters 13-23 that contain a lengthy section of 'oracles against the nations' (Williamson 1994:118). ${ }^{1}$ The order of events as described in chapters 1-12 introduces the reader to both Judah's and Jerusalem's experiences of disaster, trauma and, here and there, a few glimmers of hope. We read of the gradual destruction of God's vineyard by Assyria, Ahaz' replacement by Immanuel, the trial and hardship the prophet and those who stand with him will face, the sudden halt and final defeat of Assyria and the rise of a new king and new Israel. This presentation reaches a kind of crescendo in chapters 11-12 (Seitz 1993:120-121). The passage in Isaiah 12 is an appropriate conclusion to this first section of the BI, as the threats, imprecations, predictions of disaster, experiences of trauma, as well as the assurances of wellbeing - though less prominent in this section - are concluded on a high note (Blenkinsopp 2000:269-270).

While the scroll of Isaiah (Is 1) commences on a traumatic note and 'is particularly filled with oracles that pummel its audiences with images of human corruption and horrific warnings of impending doom' (Stulman \& Kim 2010:28; cf. also Groenewald 2016), ${ }^{2}$ Isaiah 12 at the end of the first major section imagines hope that will overcome the trauma on the way to possible joy (12:1-6) (cf. Stulman \& Kim 2010:43). For the survivors - the remnant (שְָָׁריד - 1:9) - the fact they fell just short of destruction meant survival (Carr 2014:52; cf. also Kaiser 1983:269).

Isaiah 12 has a number of connections with the preceding chapters, which suggest that it was either purposefully inserted - or even composed - to function as a conscious conclusion for the first section of the BI (Williamson 1994:118). ${ }^{3}$ This chapter, which is only six verses long, gives a voice to faithful Israel. It is formulated in the language of the Psalter, namely an eschatological hymn of praise. ${ }^{4}$ Isaiah 12 responds to the experience of survival, viz. God's salvation to his people in Zion, which is also recorded in chapters 1-11 (Childs 2001:107).

\section{Structure and redaction of the text}

Isaiah 12 is a short chapter that is only six verses long. Although some scholars regard the two introductions in v. 1 and v. 4 as marking two separate hymns (cf. Ackroyd 1978:36; Amzallag

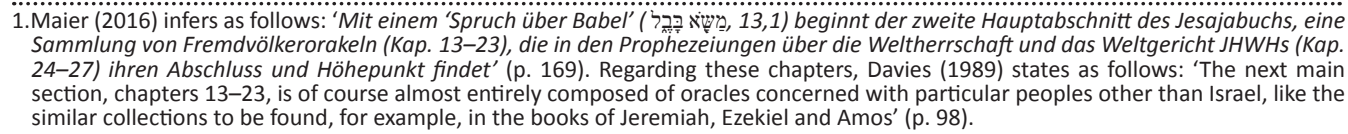

2.In this regard, Stulman and Kim (2010) furthermore infer as follows: 'The opening oracle of the entire scroll even makes the stinging accusation that faithful Zion has become a harlot (1:21-23) (p. 37).' This name-calling of the beloved city is all the more disturbing in an honor-shame culture: 'For you shall be ashamed ... and you shall blush' (1:29). With little warning, the divide between corrupt leaders and tainted people is blurred, presumably in their mutual moral contamination and their collective numbness to injustice: 'You rulers of Sodom! ... You people of Gomorrah!' (1:10).

3.Jenkins (1989:237) noted nearly 30 years ago that there 'has been growing recognition that the thematic and theological connections between the so-called First, Second and Third Isaiah cannot be accidental'. He continues that there: 'is a realisation that the final form of Is 1-39 has not come about by chance, that it is not simply a compendium of unrelated items of prophetic material with only of Is 1-39 has not come about by chance, that it is not simply a compendium of unrelated items of prophetic material with on
superficial connections, but that there are patterns to be discerned which point to a deliberate arrangement' (Jenkins 1989:238).

4.According to Kaiser (1983:269), this is an 'eschatological hymn of thanksgiving'. Furthermore, it is interpreted as a 'song of thanksgiving' (Watts 2005:220) or a 'concluding hymn of thanksgiving' (Sweeney 1996:198). 
2016:362; Beuken 2003:330-331; Brueggemann 1998:109; Kim 2016:77-78; Oswalt 1986:291), the situation may be somewhat more complex as shifts in the number and gender of those addressed occur throughout these six verses (Tull 2010:245). Verse 1 addresses a masculine singular addressee with the words 'and you will say in that day' and verses $2-3$ celebrate what God has done for 'me'. The introductory phrase of v. 1 is repeated in v. 4, albeit addressed to a plural masculine audience: 'and you (masc. pl.) will say in that day'. It though seems that these plurals are already anticipated in v. 3 when it is said that 'you all' (second masculine plural) will draw water with rejoicing from the wells (or springs) of salvation (cf. Roberts 2015:192-193). It is thus not surprising that some scholars divide the chapter as follows: vv. 1-2 and vv. 3-6 (Tull 2010:245; cf. Childs 2001:108; Goldingay 2008:88-90; Sweeney 1996:198; Watts 2005:219-220).

In the final verse, the addressee is changed once again and is directed towards a feminine singular 'Zion'. This city, and those who dwell in it, is now ordered to shout aloud, exult and sing for joy 'for great in your midst is the Holy One of

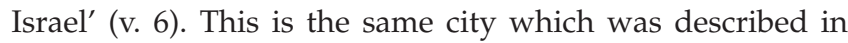
Isaiah 1:8 as sitting 'like a booth in a vineyard' and the same city which was told in 1:22 that 'your silver has become dross, your wine is mixed with water'. According to Tull (2010:246) these three addressees (masc. singular 'you', masc. plural 'you' and 'Zion') who are called to praise one after another, anticipate the three primary entities invoked repeatedly in Isaiah 40-66. Based on these observations - and in accordance with Prinsloo's analysis (1992:27-28) - she comes to the following conclusion:

Because of the continuity of purpose and theme throughout Isaiah 12 , and the interconnections among these three addressees who ultimately represent one population, this complex hymn is best viewed as a single work. (Tull 2010:246)

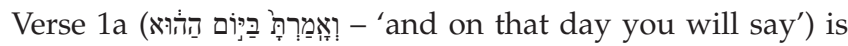
followed by direct speech in which the supplicant expresses his intention to praise YHWH for turning away his anger (vv. 1b-2b). The motivating כִ clearly indicates that YHWH is not praised because of his anger, but for the fact that he is turning away his wrath and anger, which had caused extreme traumatic experiences (Prinsloo 1992:27). Isaiah 5:25 puts to words this extreme experience of trauma:

Therefore, the anger of YHWH was kindled against his people, and he stretched out his hand against them and struck them; the mountains quaked, and their corpses were like refuse in the streets. For all this his anger has not turned away, and his hand is stretched out still. ${ }^{5}$

According to Isaiah 10:5, Assyria is the instrument used by YHWH to exercise his anger against the nation: 'Ah, Assyria, the rod of my anger - the club in their hands is my fury'.

Within the larger trauma context of Isaiah 1-11, the phrase 'I will trust, and will not be afraid' (v. 2a) stresses the hope of the supplicant that eventually trust will lead to the exclusion 5.See also the repetition of the following phrase: 'For all this his anger has not turned away; his hand is stretched out still' (Is 9:11, 16, 20; 10:4). of all fear. It is conspicuous that the noun ישוּעָה [salvation] is repeated three times in vv. 2-3 (12:2a.2b.3a). This occurrence emphasises a crucial point at stake in these verses, namely the hope expressed that 'in that day' (1a) the comprehensive salvation accomplished by $\mathrm{YHWH}$ will cause the trauma to come to an end (Prinsloo 1992:28).

A string of imperatives connect vv. $4 \mathrm{a}, 4 \mathrm{~b}$ and $5 \mathrm{a}$ together:

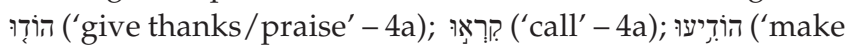

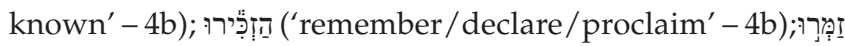

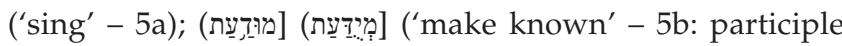
has jussive function and may therefore also be included).

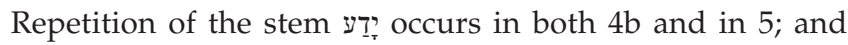

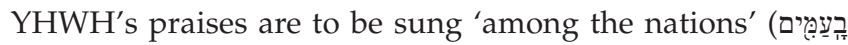

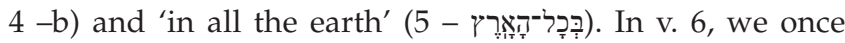
again have a change of addressee: the 'inhabitant of Zion' (יוֹשֶבֶת - second person singular), who is summoned to shout and sing for joy by means of two successive

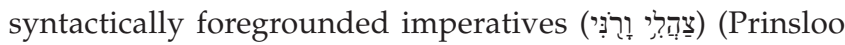
1992:28-29).

Having given a brief overview of the structure of the text, some remarks will be made regarding the redaction of this text. This chapter's redactional development is inextricably linked to its theological function within the larger literary context of the BI (Childs 2001:109). Chapter 12 forms the concluding chapter of the first section of the written corpus of Isaianic oracles (Is 1-12). It concludes chapters 1-11 and offers a holistic reading of the Isaianic message in view of the previous chapters. The major point to be made, according to Childs (2001), is namely that:

chapter 12 presents the voice of the faithful remnant of Israel responding to the great deeds of God, both in judgment and redemption, which had occupied the prophets throughout the former chapters. Up to now there had been the promise of a new community of faith that would emerge from the ashes of Israel's destruction, but the actual voice of the remnant ${ }^{6}$ had not been heard. (p. 109)

Ackroyd (1978:38-40) infers that the name of the prophet

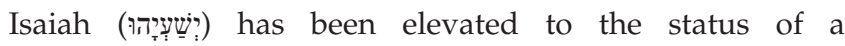
theologoumenon in the threefold occurrence of the noun שִָּּ: [salvation] in Isaiah 12:2-3. Subsequently, with the creation of Isaiah 12 , the Isaianic tradition has provided 'an interpretative comment on what precedes, drawing out in a final poetic statement the broadest significance of the prophet's person and message' (Ackroyd 1978:40). In this regard, Beuken (2000:144) justly remarks that:

the prophet who once brought a message of doom, is also presented, in the aftermath of the judgement, as a messenger of salvation, and is thereby allowed to figure as the prophet of Isaiah 40-66. ${ }^{7}$

6.For a discussion of the 'remnant' compare Conrad (1991:89) and Groenewald (2011b:100-102)

7.See also Ackroyd (1978): 'But in ii 1, stressing the Isaianic authority of the message of promise of ii $2-5$, and in the colophon, with its emphasis on the salvation of God echoing the prophet's name, and linked to the variety of hopeful words which intersperse the chapters, there is drawn out most clearly the significance of this prophet, the messenger of doom, now fulfilled, as he is also presented as messenger of salvation' (p. 45). 
In his analysis of Isaiah 12, Mathys (1994:188-200) indicates the importance of the Exodus for Isaiah 12's position within the final redaction of the BI. The exodus is not only an important theme in Isaiah 11:11-16 (where it is applied to the end of the exile), but it is also present in Isaiah 12:2 through a quotation from Exodus 15:2 ('The Lord is my strength and my might, and he has become my salvation') (Mathys 1994:190-191; cf. also Amzallag 2016:370; cf. also Beuken 2000:145-146). In this context, the phrase 'with joy you will draw water from the wells of salvation' (Is 12:3) may refer to the event where water was provided to the people in the desert (Ex 17:6; Num 20:11). ${ }^{8}$ Given the fact that the name of the prophet Isaiah is called to mind in the repetition of the word 'salvation' (Is 12:2-3), 'wells of salvation' might even be a reference to the BI as a whole (Mathys 1994:189-190).

With regard to the specific understanding and vision of the prophet in Isaiah 12, Beuken (2000:155) underlines the fact that the Isaianic tradition attached a particular interpretation to the role of Isaiah ben Amoz. It allows the prophet, who trusts in $\mathrm{YHWH}$, to combine the announcement of judgement with anticipatory thanksgiving for the salvation that would follow this trauma. The readers are thus not only confronted with the traumatic experience of God's judgement but also provided with an example of the expectation of future salvation from these traumatic experiences. This song of praise is given in advance to the readers of the BI as a song of confidence that they will overcome trauma as a fulfilment of the prophet's prophecies (Beuken 2000:156).

It seems possible to date the origin of this passage with more certainty than that of many others (Tull 2010:248). Prinsloo (1992:29) infers that we have strong arguments to regard Isaiah 12 as a post-exilic text which was intentionally composed as a colophon to Isaiah 1-11 and which subsequently performed the role of a transitional text to Isaiah 13-23. According to Tull (2010:245), Chapter 11 concludes with the hope of the coming day of deliverance from Assyria, which is described as a parallel to Israel's ancient exodus from Egypt. In Chapter 12, the prophet offers a song of celebration for this coming day of salvation, just as Moses and Miriam were leading the people in singing, dancing and celebration after their departure from Egypt (Ex 15). The song in Isaiah 12 not only recaps the story line of Isaiah 1-11 but also weaves together themes and motifs from a number of other texts. It not only functions as a transition to the next section but also anticipates major themes and speech forms the reader will encounter in Deutero-Isaiah (DI) and Trito-Isaiah (TI). ${ }^{9}$

\footnotetext{
8.In this regard, Mathys (1994:189) infers as follows: 'Da Jes 11,11ff den neue Exodus besingt, ist es nicht abwegig, in Jes 12:3 eine Anspielung darauf zu entdecken'.

9.Beuken (2000:146-150), for example, indicated a number of commonalities between Isaiah 12 and 25. For Beuken (2000:146), it seems the final redactor(s) used his (their) scribal expertise to construct a watchtower in Isaiah 12 which can allow the exegete to study the whole of the BI from this position (tower). Williamson (1994:118-125) also outlines the connections existing between this chapter and D (1994:118-125) also outlines the connections existing between this chapter and D and infers that this chapter belongs to the Proto-Isaianic redaction by DI. For him $12: 1-6$ is thus a Deutero-Isaianic composition written specifically for its presen location within Isaiah 1-39 (cf. also Stromberg 2011:38-39). Davies (1989:97) infer that the command in verse 4, to 'make known his deeds among the nations', is of special importance as it is placed just before 11 chapters (13-23) focusing on the 'nations'. This short text indeed contains some conventional lines reminding us of $D$ which also foresees the proclamation of Yahweh's great deeds to the nations.
}

This conclusion leads us to the question of the function of this text. Prinsloo (1992:29-30) furthermore argues that the text of Isaiah 12 is composed to encourage and comfort the readers who experienced extreme events of trauma. It could even be called a persuasive text as it aims to convince its readers to trust in YHWH because his anger will come to an end and turn into salvation. In a sense, Isaiah 12 is a theological interpretation of the exile, and in spite of this traumatic event, the first section of the BI culminates in thanksgiving, worship and praise of the Holy One of Israel.

\section{Isaiah 12: Trauma and resilience}

God's anger at the nation is one of the main themes repeated in chapters 1-11. This great prophetic scroll introduces the reader with the strong image of a disappointed and traumatised parent (Tull 2010:245). YHWH complains about the disloyalty of Israel: Although he raised them up like his children, they have rebelled against him (Is 1:2-3). The 'traumatised' parent complains that even an ox and an ass know their owner, but Israel does not acknowledge him. While on the one hand we read in Isaiah 1 of his anger towards Israel because of their rebellious behaviour, this chapter on the other hand also tells about YHWH's acts to bring his people back to obedience. Even the whole creation is called upon to listen and to bear witness to the accusations against Israel who have rebelled against him in spite of his loving care (Berges 1998:59; Childs 2001:17; Groenewald 2011a:3; 2016:2; Tull 2010:245).

The other major themes that are further developed in Isaiah 2-10 are accusations of arrogance, human pride and injustices (Tull 2010:245). These accusations justify the divine judgement against Israel in the form of attacks by Assyria, a nation used by $\mathrm{YHWH}$ as an instrument to punish his rebellious people (cf. also Davies 1989:96). It can thus be assumed that both $\mathrm{YHWH}$ and the people are traumatised as a result of this situation. It is now only in Chapter 10 that divine wrath turns against the aggressor as Assyria oversteps all boundaries and their pride threatens YHWH's sovereignty (see also Davies 1989:96). In Chapter 11, the prophet imagines a new beginning for kingship and nation, and in the final chapter (Chapter 12) of this first section, he anticipates Israel saying: 'though you were angry with me, your anger turned away, and you comforted me' (12:1) (Tull 2010:245). ${ }^{10}$

The Isaianic tradition takes the reader beyond trauma to survival of trauma. In concluding this first section of the BI, the prophet demands praise to God as hope comes, first and foremost, from God. Hope looks beyond the present realities and leads to a transformation that reaches beyond the set boundaries of past experiences and perspectives (Stulman \& Kim 2010:41-46).

10.Zenger (1997:143-144) remarks as follows in this regard: Auf der Ebene der Endkomposition von Jes 1-12 gehört Jes 11,1-10 zu dem Komplex Jes 10,5-12,6, der sich zusammen mit dem Komplex Jes 1,2-4,6 um den Mittelteil Jes 5,1-10,4 der sich zusammen mit dem Komplex Jes 1,2-4,6 um den Mittelteil Jes 5,1-10,4
legt. Während 10,5-34 das Gericht über Assur und damit die Rettung Zion vor äuberer Bedrohung ankündigt, entfaltet 11,1-10 die Rettung Israels von innerer
än Bedrohung und die dadurch ausgelöste Wallfahrt der Völker zu diesem Ort der Bedrohung und die dadurch ausgelöste Wallfahrt der Völker zu diesem Ort der
Offenbarung des כוד Zu diesem Ort strömt der »Rest seines Volkes" (11,11-20) und singt das Danklied der Rettung durch den endgültigen Exodus (Jes 12). 


\section{Conclusion}

The focus in this article was on the structure and redaction of Isaiah 12, a song that brings the first major section of the BI to a close. This text was interpreted as a meaning-making text against the background of trauma as described in this first main section of the BI. This text transcends the reader beyond trauma and anticipates resilience and survival. Isaiah 12 gives Judah a song to sing as they hope God will do something remarkable for his people. The first major section tells the reader of confrontation, warning and promise. The Isaianic community is invited to live within this story, to be resilient and to live in hope (Goldingay 2015:52-53).

\section{Dedication}

This article is dedicated to my colleague Prof. Yolanda Dreyer who has always been an important theological discussion partner.

\section{Acknowledgements Competing interests}

The author declares that he has no financial or personal relationships which may have inappropriately influenced him in writing this article.

\section{References}

Ackroyd, P.R., 1978, 'Isaiah I-XII: Presentation of a prophet', in W. Zimmerli (ed.) Congress Volume Göttingen 1977, pp. 16-48, Brill, Leiden. (VTS 29).

Amzallag, N., 2016, 'The Paradoxical Source of Hope in Isaiah 12', Revue Biblique 123(3), 357-377. https://doi.org/10.2143/RBI.123.3.3159681

Berges, U., 1998, Das Buch Jesaja: Komposition und Endgestalt, Herder, Freiburg. (HBS 16).

Beuken, W.A.M., 2000, 'The Prophet leads the Readers in Praise. Isaiah 25:1-10 in Connection with Isaiah 24:14-23 seen against the Background of Isaiah 12', in H.J. Bosman, H. van Grol, et al. (eds.), Studies in Isaiah 24-27. The Isaiah WorkshopDe Jesaja Werkplaats, pp. 121-156, Brill, Leiden. (OTS, XLIII).

Beuken, W.A.M., 2003, Jesaja 1-12, Herder, Freiburg i.Br. (Herders Theologischer Kommentar zum Alten Testament).

Blenkinsopp, J., 2000, Isaiah 1-39. A New Translation with Introduction and Commentary, Yale University Press, New Haven, CT. (Anchor Yale Bible 19).

Brueggemann, W., 1998, Isaiah 1-39, Westminster John Knox Press, Louisville, KY. (Westminster Bible Companion).
Carr, D.M., 2014, Holy Resilience. The Bible's Traumatic Origins, Yale University Press, New Haven, CT.

Childs, B.S., 2001, Isaiah, Westminster John Knox, Louisville, KY. (OTL).

Conrad, E.W., 1991, Reading Isaiah, Fortress Press, Minneapolis, MN. (Overtures in Biblical Theology).

Davies, G., 1989, 'The Destiny of the Nations in the Book of Isaiah', in J. Vermeylen (ed.), The Book of Isaiah - Le Livre d'Isaïe. Les oracles et leurs relectures unité et complexité de l'ouvrage, pp. 93-120, Peeters, Leuven. (BETL 81).

Goldingay, J., 2008, Isaiah, Hendrickson Publishers, Peabody, MA. (NIBC).

Goldingay, J., 2015, Isaiah for everyone, SPCK, London.

Groenewald, A., 2011a, 'Isaiah 1:2-3, ethics and wisdom. Isaiah 1:2-3 and the Song of Moses (Dt 32): Is Isaiah a prophet like Moses?', HTS Teologiese Studies/Theological Studies 67(1), Art. \#954, 1-6. https://doi.org/10.4102/hts.v67i1.954

Groenewald, A., 2011b, 'Isaiah 1:4-9 as a post-exilic reflection', JSEM 20(1), 87-108.

Groenewald, A., 2016, 'The transformation of the city of Zion: From decadence to justice and prophetic hope (Is. 1:1-2:5)', HTS Teologiese Studies/Theological Studies 72(1), a3568. https://doi.org/10.4102/hts.v72i1.3568

Jenkins, A.K., 1989, 'The Development of the Isaiah Tradition in Is 13-23', in J. Vermeylen (ed.), The Book of Isaiah - Le Livre d'Isaïe. Les oracles et leurs relectures unité et complexité de l'ouvrage, pp. 237-251, Peeters, Leuven. (BETL 81).

Kaiser, O., 1983, Isaiah 1-12. A Commentary, SCM Press, London. (OTL).

Kim, H.C.P., 2016, Reading Isaiah. A Literary and Theological Commentary, Smyth \& Helwys, Macon, GA. (Reading the Old Testament).

Maier, M.P., 2016, Völkerwallfahrt im Jesajabuch, De Gruyter, Berlin. (BZAW 474).

Mathys, H.-P., 1994, Dichter und Beter: Theologen aus der spätalttestamentlicher Zeit, Universitätsverlag, Freiburg. (OBO 132).

Oswalt, J.N., 1986, The Book of Isaiah. Chapters 1-39, Eerdmans Publishing, Grand Rapids, MI. (NICOT).

Prinsloo, W.S., 1992, 'Isaiah 12: One, Two or Three Songs?', in K.-D. Schunck \& M. Augustin (eds.), Goldene Äpfel in silbernen Schalen. Collected Communications to the XIIIth Congress of the International Organization for the Study of the Old Testament, Leuven 1989, pp. 25-33, Peter Lang, Frankfurt. (Beiträge zur Erforschung des Alten Testaments und des Antiken Judentums 20).

Roberts, J.J.M., 2015, First Isaiah. A Commentary, Fortress Press, Minneapolis, MN (Hermeneia).

Seitz, C.R., 1993, Isaiah 1-39, John Knox Press, Louisville, KY. (Interpretation).

Stromberg, J., 2011, An Introduction to the Study of Isaiah, T\&T Clark, London. (T\&T Clark Approaches to Biblical Studies).

Stulman, L. \& Kim, H.C.P., 2010, You are my people. An introduction to prophetic literature, Abingdon Press, Nashville, TN.

Sweeney, M.A., 1996, Isaiah 1-39 with an introduction to prophetic literature, Eerdmans, Grand Rapids, MI. (FOTL 16).

Tull, P.K., 2010, Isaiah 1-39, Smyth \& Helwys, Macon, GA. (Smyth \& Helwys Bible Commentary)

Watts, J.D.W., 2005, Isaiah 1-33 (revised edition), Thomas Nelson, Nashville, TN. (WBC 24).

Williamson, H.G.M., 1994, The Book Called Isaiah. Deutero-Isaiah's Role in Composition and Redaction, Clarendon Press, Oxford.

Zenger, E., 1997, 'Die Verheissung Jesaja 11,1-10 - Universal oder partikular?', in J. van Ruiten \& M. Vervenne (eds.), Studies in the Book of Isaiah. Festschrift Willem A.M. Beuken, pp. 137-147, Peeters, Leuven. (BETL CXXXII). 